\title{
Yozgat Yöresinde Geriatrik Yaș Grubunda Görülen Deri Hastalıklarının Prevalansı*
}

\author{
Prevalence of Skin Diseases Among Geriatric Patients in The Region of Yozgat \\ Emine Çölgeçen ${ }^{1}$, Elif Börekçi², Çiğdem Kader ${ }^{3}$, Tekin Yıldırım², Kemal Özyurt ${ }^{4}$
}

Bozok Üniversitesi Tıp Fakültesi, Dermatoloji Ana Bilim Dalı, Yozgat

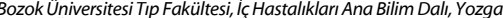
Bozok Universitesi Tıp Fakültesi, Enfeksiyon Hastalıkları ve Klinik Mikrobiyoloji Ana Bilim Dali, Yozgat

Hastanesi, Dermatoloji Bölümü, Kayseri

Bu çalışma 21-25 Ekim 2014 tarihlerinde Antalya'da gerçekleşen 25. Ulusal Dermatoloji Kongresi'nde poster bildirisi olarak sunulmuştur.

Geliș tarihi : 08.06.2015• Kabul tarihi: 23.10.2015

Iletișim

Yrd. Doç. Dr. Emine Çölgeçen

Tel: 03542127060

Faks: 03542177150

E-posta: drecolgecen@hotmail.com

E-posta: drecolgecen@hotmail.com

66000 Yozgat
Amaç: Ülkemizde yașlı popülasyonun giderek artması ile yașlanmaya bağlı deri değișiklikler ve hastalıkları artmıștır. Bu çalıșmada bölgemizdeki yașlı hastalarda görülen deri hastalıkları ve bunların sıklığını tespit etmek amaçlanmıștır.

Gereç ve Yöntem: Yozgat Üniversitesi Tıp Fakültesi Dermatoloji Polikliniği'ne Ekim 2010 Mayıs 2014 tarihleri arasında bașvuran ve yașları 65 ve daha yukarı olan 1110 hastanın dosyaları yaș, cinsiyet, dermatolojik muayene ve tanı bilgileri retrospektif olarak incelenmiștir.

Bulgular: Calıșmaya alınan hastaların 530'u (\%47.7) kadın, 580'i (\%52.3) erkekti. Yas ortalaması $72.3 \pm 6.2$ olarak saptandı. Tespit edilen deri hastalıkları 11 grupta incelenmiștir. Bunlar sıklık sırasına göre; \%31.9 enfeksiyöz dermatozlar, \%14.1 enflamatuvar deri hastalıkları, \%12.7 pruritus, \%9.4 deri tümörleri, \%9.3 diğer deri hastalıkları, \%9 kserozis, \%6.8 immunolojik deri hastalıkları, \%3.2 epidermal kalınlașmalar, \%1.4 vasküler değișiklikler, \%1.3 deri eki hastalıkları ve \%1.1 UV bağlı dermatozlardı.

Sonuç: Bölgemizde daha önce benzer bir çalıșma yapılmamıs olması nedeni ile çalıșmamız Yozgat ilinde geriatrik yaș grubunda görülen deri hastalıkları hakkında bilgi vermektedir. Geriatrik hastalarda görülen dermatolojik problemler ve sıklık oranları, Türkiye'nin çeșitli illerindek merkezler arasında yapılan çalıșmalarda değișkenlik göstermektedir. Ülkemizde geriatrik yaș grubunda görülen dermatolojik hastalıkları tam olarak tespit etmek ve gerekli önlemleri almaḱ için aynı zaman diliminde yapılacak, prospektif, çok merkezli yeni çalıșmalara ihtiyaç olduğunu düșünmekteyiz.

Anahtar Sözcükler: Yașlı, Deri Yașlanması, Deri Hastalıkları

Aim: With the increasing growth of the elderly population in Turkey, there has also been an increase in age-related skin changes and diseases. The purpose of this study was to identify skin diseases in the elderly population in our region and to determine their prevalence.

Materials and Methods: The records of 1110 patients aged over 65 and presenting to the Yozgat University Faculty of Medicine Dermatology Clinic between October 2010 and May 2014 were examined retrospectively in terms of age, gender, dermatological examination and diagnostic data.

Results: Five hundred thirty (47.7\%) of the patients included in the study were women and $580(52.3 \%)$ were men. Mean age was $72.3 \pm 6.2$. Skin diseases identified were examined under 11 groups. In order of prevalence, these were $31.9 \%$ infectious dermatoses, $14.1 \%$ inflammatory skin diseases, $12.7 \%$ pruritus, $9.4 \%$ skin tumors. $9.3 \%$ other skin diseases, $9 \%$ xerosis, $6.8 \%$ immunological skin diseases, $3.2 \%$ epidermal thickening, $1.4 \%$ vascular changes, $1.3 \%$ cutaneous adnexal diseases and $1.1 \%$ UV-related dermatoses.

Conclusion: Our study, performed due to the absence of any previous similar research in the region, provides information about skin diseases seen in the geriatric age group in the province of Yozgat. Dermatological problems and the prevalences thereof in geriatric patients vary in studies from different provinces of Turkey. We think that further prospective, multi-center studies performed in the same time period are needed in order to accurately identify dermatological problems seen in the geriatric age group in Turkey, and for appropriate measures to be taken.

Key Words: Aged, Skin Aging, Skin Diseases 
Gelişmiş ülkelerin yanı sıra gelişmekte olan ülkelerde de giderek yaşlı nüfus artmaktadir. Bunun sonucu ileri yaşlara bağlı deri değişiklikleri ve hastalıkları artış göstermektedir. Yaşlanma ile beraber derinin epidermis tabakasında hücre sayısı azalır. Dermisin yüzeyel yağ tabakasinda, hidrasyonunda, elastisitesinde ve kalınlığında azalma olur. Böylece yaşlı hastalarda deri incelerek travmalara daha açık hale gelir, yağ ve ter bezlerinde, dermal kollajen ve elastik liflerde meydana gelen değişikliklerle daha sarkı1k ve kırısık bir görünüm alır (1-3). Melanosit ve Langerhans hücrelerinin sayısı azalır. Deride kahverengi lekeler, saçlarda seyrekleşme ve grileşme olur. Tirnaklar incelir ve uzaması yavaşlar $(4,5)$.

Yaşlılarda deri hastalıkları sık görülmekte ve toplumun bu hastalıkların önemi konusunda duyarlılığ da gittikçe artmaktadır. Yaşlilıkta görülen deri hastalıklarının büyük bir kısmı, kişinin yaşamını tehdit etmese de yaşam kalitesini olumsuz yönde etkilemektedir $(1,6)$. Ülkemizde yaşlı nüfusta görülen deri hastalıkları ile ilgili az sayıda epidemiyolojik çalışma vardır ve bölgemizde daha önce bu konuda yapılmış bir çalışma bulunmamaktadır. Bu çalışmada Yozgat yöresindeki yaşlı hastalarda görülen deri hastalıklarını ve bunların görülme sıklığını tespit etmek amaçlanmıştır.

\section{GEREÇ VE YÖNTEMLER}

Ekim 2010 - Mayıs 2014 tarihleri arasında Yozgat Üniversitesi Tip Fakültesi Dermatoloji Polikliniğine başvuran 65 yaş ve üzeri hastalar poliklinik kayıtlarından taranmıştır. Dosyalarına ulaşılabilen ve dosyasında yeterli bilgi bulunan 1110 hasta çalışma kapsamına alınmıştır. Çalışma retrospektif olarak planlanmıştır. Hastaların yaşlar1, cinsiyeti, dermatolojik bulguları ve tanıları kaydedilmiştir. Hastalar erken yaş grubu (65-75 y) ve ileri yaş grubu (75 yaş üzeri) olarak sınıflandırılmıştır.

Çalışmaya alınan hastalarda saptanan deri hastalıkları; enfeksiyöz dermatozlar, enflamatuvar deri hastalıkları, deri tümörleri, kserozis, pruritus, vasküler değişiklikler, epidermal kalınlaşmalar, immunolojik deri hastalıkları, ultraviyole (UV)'ye bağlı dermatozlar, deri eki hastalıkları ve çeşitli hastalıklardan oluşan diğerleri olarak 11 ana başlık altında gruplandırılmıştır.

İstatistiksel analizde yaş grupları, cinsiyetler ve hastalıklar arasındaki ilişkilerin değerlendirilmesinde "ki-kare" testi uygulandı ve değerlendirme yapılırken $\mathrm{p}<0.05$ ise anlamlı kabul edildi.

\section{BULGULAR}

Yaşları 65 ile 95 arasında değişen toplam 1110 hastanın yaş ortalaması $72.3 \pm 6.2$ olarak tespit edildi. Hastalarin 530'u (\%47.7) kadın, 580'i (\%52.3) erkekti. Erken yaş grubunda 803 hasta $(\% 72.3)$, ileri yaş grubunda ise 307 hasta $(\% 27.7)$ saptand. Her iki yaş grubundaki cinsiyet dağılımları arasinda anlamlı bir fark yoktu ( $>>0.05)$ (Tablo 1).

Hastalarda tanı koyulmuş sistemik hastalik olarak en sik diabetes mellitus $(\% 23)$ ve hipertansiyon $(\% 57)$ olduğu gözlendi. Ayrıca \%53 oraninda en az bir sistemik hastalık ve bu nedenle ilaç kullanımı mevcuttu.

On bir ana başlık altında sınıflandırılan dermatolojik hastalıklar s1klik sirasına göre değerlendirildiğinde; 354 (\%31.9) hastada enfeksiyöz dermatozlar, 156 \%14.1) hastada enflamatuvar deri hastalıkları, $141(\% 12.7)$ hastada pruritus, $104(\% 9.4)$ hastada deri tümörleri, $100(\% 9)$ hastada kserozis, 75 (\%6.8) hastada immunolojik deri hastalıkları, $36(\% 3.2)$ hastada epidermal kalınlaşmalar, 15 (\%1.4) hastada vasküler değişiklikler, 14 (\%1.3) hastada deri eki hastalıkları, $12(\% 1.1)$ hastada UV'ye bağlı dermatozlar ve 103 (\%9.3) hastada diğer deri hastalıkları saptand1 (Tablo 2).

Çalışmamızda 65 yaş üstü hastalarda en s1k görülen hastalık grubu enfeksiyöz dermatozlar olarak belirlendi. En s1k saptanan hastalik grubu olan enfeksiyöz dermatozlar; yüzeyel mantar hastalıkları, viral enfeksiyonlar, bakteriyel enfeksiyonlar ve paraziter hastalıklar olarak dört gruba ayrild1. Bu grup içinde yüzeyel mantar hastalıkları ilk sırada yer alırken, mantar hastalıkları arasında ise hastaların \%36.8'inde görülen tinea pedis ve onikomikoz birlikteliği ilk sıradaydı. Tinea pedis ve onikomikoz sıklığ1 diabetik hastalar ile diabeti olmayan hastalar arasinda karşılaştırıldığında anlamlı bir ilişki bulunmadığ1 gözlendi ( $\mathrm{p}>0.05)$. Cinsiyetlere göre dağılımda da anlamlı fark yoktu. Diğer enfeksiyöz dermatozlardan viral enfeksiyonlar \%19.5,

Tablo 1: Hastaların yaş grupları ve cinsiyetlere göre dağılımı

\begin{tabular}{|l|c|c|c|c|c|c|}
\hline & \multicolumn{4}{|c|}{ Cinsiyet } & \multicolumn{2}{c|}{ Toplam } \\
\hline Yaș grupları & Kadın & $\%$ & Erkek & $\%$ & Sayı & $\%^{*}$ \\
\hline $65-75$ & 386 & 48.1 & 417 & 51.9 & 803 & 72.3 \\
\hline$>75$ & 144 & 46.9 & 163 & 53.1 & 307 & 27.7 \\
\hline Toplam & $\mathbf{5 3 0}$ & $\mathbf{4 7 . 7}$ & $\mathbf{5 8 0}$ & $\mathbf{5 2 . 3}$ & $\mathbf{1 1 1 0}$ & $\mathbf{1 0 0 . 0}$ \\
\hline
\end{tabular}

*Sütun yüzdesidir, diğerleri satır yüzdesidir.

Tablo 2: Hastalık grupları

\begin{tabular}{|l|c|c|}
\hline & Sayı & $\%$ \\
\hline 1. Enfeksiyöz dermatozlar & 354 & 31.9 \\
\hline 2. Enflamatuvar deri hastalıkları & 156 & 14.1 \\
\hline 3. Pruritus & 141 & 12.7 \\
\hline 4. Deri tümörleri & 104 & 9.4 \\
\hline 5. Kserozis & 100 & 9 \\
\hline 6. İmmunolojik deri hastalıkları & 75 & 6.8 \\
\hline 7. Epidermal kalınlașmalar & 36 & 3.2 \\
\hline 8. Vasküler değișiklikler & 15 & 1.4 \\
\hline 9. Deri eki hastalıkları & 14 & 1.3 \\
\hline 10. UV bağlı dermatozlar & 12 & 1.1 \\
\hline 11. Diğer deri hastalıkları & 103 & 9.3 \\
\hline
\end{tabular}


Tablo 3: Enfeksiyöz dermatozlar

\begin{tabular}{|l|c|c|}
\hline Mantar hastalıkları & Sayı & $\%$ \\
\hline Tinea pedis+Onikomikoz & 88 & 24.9 \\
\hline Tinea pedis & 66 & 18.6 \\
\hline Tinea inguinalis & 36 & 10.2 \\
\hline Onikomikoz & 28 & 7.9 \\
\hline Tinea corporis & 10 & 2.8 \\
\hline Tinea versicolor & 6 & 1.7 \\
\hline Tinea manum & 5 & 1.4 \\
\hline Viral enfeksiyonlar & Sayı & $\%$ \\
\hline Zona zoster & 50 & 14.1 \\
\hline Verruka vulgaris & 13 & 3.7 \\
\hline Anogenital verrü & 3 & 0.8 \\
\hline Herpes simplex & 3 & 0.8 \\
\hline Bakteriyel enfeksiyonlar & Sayı & $\%$ \\
\hline Follikülit & 17 & 4.8 \\
\hline Selülit & 14 & 3.9 \\
\hline Fronkül & 11 & 3.1 \\
\hline Paraziter hastalıklar & Sayı & $\%$ \\
\hline Uyuz & 5 & 1.4 \\
\hline
\end{tabular}

Tablo 4: Enflamatuvar deri hastalıkları

\begin{tabular}{|l|c|c|}
\hline Ekzemalar & Sayı & \% \\
\hline Kontakt dermatit & 31 & 19.9 \\
\hline Seboreik dermatit & 27 & 17.3 \\
\hline Kserotik ekzema & 26 & 16.7 \\
\hline Nörodermatit & 16 & 10.3 \\
\hline Atopik dermatit & 6 & 3.8 \\
\hline Numuler dermatit & 3 & 1.9 \\
\hline Staz dermatiti & 1 & 0.6 \\
\hline Papüloskuamöz hastalıklar & Sayı & $\%$ \\
\hline Psöriazis & 28 & 17.9 \\
\hline Liken planus & 10 & 6.4 \\
\hline Pitriazis rozea & 4 & 2.6 \\
\hline Parapsöriazis & 2 & 1.3 \\
\hline Pitriyazis likenoides kronika & 2 & 1.3 \\
\hline
\end{tabular}

Tablo 5: Deri tümörleri

\begin{tabular}{|l|c|c|}
\hline Malign deri tümörleri & Sayı & $\%$ \\
\hline Bazal hücreli karsinom & 9 & 8.7 \\
\hline Skuamöz hücreli karsinom & 3 & 2.9 \\
\hline Mikozis fungoides & 2 & 1.9 \\
\hline Kaposi sarkomu & 1 & 0.9 \\
\hline Premalign deri tümörleri & Sayı & $\%$ \\
\hline Aktinik keratoz & 42 & 40.4 \\
\hline Benign deri tümörleri & Sayı & $\%$ \\
\hline Seboreik keratoz & 24 & 23.1 \\
\hline Fibrom & 12 & 11.5 \\
\hline Piyojenik granülom & 4 & 3.8 \\
\hline Lipom & 2 & 1.9 \\
\hline Epidermal kist & 1 & 0.9 \\
\hline Ksantom & 1 & 0.9 \\
\hline Venöz göllenme & 1 & 0.9 \\
\hline Benign sebase hiperplazi & 1 & 0.9 \\
\hline Dermatofibrom & 1 & 0.9 \\
\hline
\end{tabular}

bakteriyel enfeksiyonlar \%11.9 ve paraziter hastalıklardan uyuz \%1.4 oranında görüldü (Tablo 3).

İkinci s1k rastlanan grubu ise $156(\% 14.1)$ hasta ile enflamatuvar deri hastalıkları olușturdu. Bu grupta ekzemalar \%10 ve papüloskuamöz hastalıklar da \%4.1 sıklıkta saptanmıştır (Tablo 4).

Hastalarda en s1k rastlanan üçüncü hastalik grubu pruritus (\%12.7) idi. Dördüncü sirayı alan deri tümörleri (\%9.4); malign, premalign ve benign deri tümörleri olarak üç gruba ayrıldı. Malign tümörlerin arasinda en s1k görülen tümörler $9(\% 8.7)$ hasta ile bazal hücreli karsinomdu. İkinci sırada $3(\% 2.9)$ hasta ile skuamöz hücreli karsinom yer almaktaydı. Premalign hastalık alt grubunda $42(\% 40.4)$ hastada aktinik keratoz tespit edildi. Benign tümörler içinde en sık görülenler seboreik keratoz (\%23.1), fibrom $(\% 11.5)$ ve piyojenik granülom (\%3.8) idi (Tablo 5).

Kserozis $100 \quad(\% 9)$ hastada gözlendi. Kserozis yaş grupları ve cinsiyete göre anlamlı farkl1lık gösteriyordu. İleri yaş grubunda ve kadın cinsiyette istatistiksel olarak daha fazla oranda kserozis saptand $1(\mathrm{p}<0.05)$.

İmmünolojik deri hastalıkları $75(\% 6.8)$ hastada tespit edildi. Bunlar; 57 (\%5.1) hastada ürtiker, $8(\% 0.7)$ hastada büllü hastalıklar, $8(\% 0.7)$ hastada ilaç reaksiyonları ve $2(\% 0.2)$ hastada kollajen doku hastalıkları şeklinde dağılım göstermekteydi.

Epidermal kalınlaşmalar (korn, kallus, plantar hiperkeratoz) $36(\% 3.2)$ hastada, vasküler değişiklikler (senil ekimoz, pigmente purpurik dermatoz) $15(\% 1.4)$ hastada saptand.

Deri eki hastalıkları $14(\% 1.3)$ hastada tespit edildi. Bunlar da; $8(\% 0.7)$ hastada alopesi areata, $2(\% 0.2)$ hastada onikogrifoz, $2(\% 0.2)$ hastada miliarya rubra, $1(\% 0.1)$ hastada jeneralize hiperhidroz ve $1(\% 0.1)$ hastada da tırnak batması şeklinde dağılım göstermekteydi.

On iki (\%1.1) hastada UV nedeniyle oluşan dermatozlar gözlendi. Altı $(\% 0.5)$ hastada elastoz ve derin kır1- 
ş1klıklar görülürken, $3(\% 0.3)$ hastada polimorf 1 şı erüpsiyonu, $2(\% 0.2)$ hastada fotokontakt dermatit ve 1 (\%0.1) hastada da aktinik retiküloid mevcuttu.

Yüz üç (\%9.3) hastada diğer hastalıklar tespit edildi. Bunlar sıklık sırasina göre; 46 (\%4.1) hastada rozase, 14 $(\% 1.3)$ hastada insecbite, $13(\% 1.2)$ hastada coğrafik dil, $12(\% 1.1)$ hastada vitiligo, $10(\% 0.9)$ hastada rekürren aftöz stomatit, $4(\% 0.4)$ hastada ikinci derece yanı, $3(\% 0.3)$ hastada diyabetik ayak ve $1(\% 0.1)$ hastada pellegra saptandi.

Hastaların 320'si (\%28.8) sonbahar, 299'u (\%26.9) yaz, 291'i (\%26.2) ilkbahar, 200 'ü (\%18) ise kış mevsiminde kliniğimize başvurdu.

\section{TARTIȘMA}

Dünya nüfusunun giderek yaşlanması, tedavi olanaklarının artması, kişinin yaşamını tehdit etmemesine rağmen yaşam kalitesini olumsuz yönde etkileyen deri hastalıkları gibi çeşitli sağlık problemlerini ön plana çıkarmıştır.

Geriatrik hastalarda sık görülen nörolojik bozukluklar, immün sistemde yetersizlik, şişmanlık, beslenme bozuklukları, epidermiste hücre yenilenmesinde azalma ve kişisel bakımdaki yetersizliklerden dolayı infeksiyon hastalıklarının görülme sıklığı artmıştır. Bu çalışmada ülkemizde yapılan bazı çalışmalarda olduğu gibi hastalık gruplar1 içinde en sik enfeksiyöz dermatozlar (\%31.9) görüldü (1,7-9). Bu grup içinde yüzeyel mantar hastalıkları ilk sırada yer alırken, mantar hastalıkları arasında ise hastaların \%36.8'inde görülen tinea pedis ve onikomikoz birlikteliği ilk sıradaydı. Viral hastalık grubunda ise en s1k bulunan zona zoster (\%72.5) akut dönemde ağrisıyla yerleştiği bölgeye göre çeşitli hastalıklarla karışabilir. Kronik dönemde postherpetik nevralji gelişirse bireyin yaşam kalitesini olumsuz yönde etkileyebilir. Bu nedenle yaşlı hastalarda ilk 72. saat içinde antiviral tedavi başlanması önerilmektedir (7).

Çalışmamızda enflamatuvar deri hastalıkları içerisinde yer alan ekzemalar \%10 sıklığında saptand. Ekzemalar içinde en sik kontakt dermatit, ikinci siklıkta seboreik dermatit gözlemlendi. Yaşl1likta kontakt dermatitin sik görülmesinde epidermal bariyer fonksiyonunun bozulmasına bağlı olarak irritan ve alerjen maddelere karşı hassasiyetin artması önemli bir rol oynamaktadır. Seboreik dermatitin görülme sıklı̆̆ının bu yaş döneminde ikinci bir pik yaptığ1 bilinmektedir (6). Ülkemizde yapilan çoğu çalışmada ekzemalar yaşlı hastalarda sik görülen hastalık grupları içinde bulunmuştur $(1,3,7-11)$.

Pruritus, yaşlılarda sık görülen problemlerden birisidir. Çok fazla sayıda sistemik ve dermatolojik hastalık kaşıntıya neden olur. Deri yaşlandıkça kuru ve kaşıntılı olmaktadır. Epidermisin su tutma kapasitesinin azalması, sık yapılan sıcak banyolar, düşük çevre 1sıs1, ortam neminin az olması derinin daha çok kurumasına yol açar. Geriatrik hastaların \%75'inde kserozisin bulunduğu düşünülmektedir $(6,12)$. Türkiye'de yapılan bazı çalışmalarda pruritus \%2.6-23.5 (1,2,7-10), kserozis ise $\% 3.1-\% 45.1(2,3,7-10,13)$ arasinda değişen sıklıklarda bulunmuştur. Hastalarımızın \%12.7'sinde pruritus, $\% 9$ 'unda da kserozis tespit ettik. Kserozis görülme sıklığını banyo yapma alışkanlığ1 ve coğrafi koşullar etkileyebilir. Ayrıca retrospektif yap1lan çalışmaların çoğunda gözden kaçma olasıllŏı nedeniyle kserozis düşük bulunmuş olabilir. Türkiye'de yapılan iki prospektif çalışmada kserozis görülme sıklığının $\% 41$ ve $\% 45.1$ bulunması bu durumu desteklemektedir $(2,13)$.

Deri tümörleri, diğer yaş gruplarına göre yaşlılarda daha sık görülür. Bunlardan bazal hücreli karsinom, aktinik keratoz ve yassı hücreli karsinomun oluşumunda UV ışınlarının etkili olduğu bilinmektedir. Ülkemizde yapılan ça- lışmalarda deri tümörü sılklı̆g $\% 4,1$ ile \%81.5 arasında değişmektedir (1-3,711). Aradaki büyük farklılığın nedeni, Türkiye'de UV'ye maruziyet açısından bölgesel farklılıklar olması ve çalışma yöntemi ile ilişkili olabilir. Bu çalışmada deri tümörü sıklığını \%9.4 olarak bulduk. Deri tümörleri içinde de en sık aktinik keratozu gözlemledik.

İmmünolojik deri hastalıklarını $\% 6.8$ hastada saptadık. Bu grup içinde ürtiker ilk sırada yer alırken büllü hastalıklar ve ilaç reaksiyonları ikinci sırada yer almaktaydı. İnsanların \%1520 'sinin yaşamı boyunca en az bir kez ürtiker atağı geçirdiği bilinmektedir. Büllü hastalıklardan özellikle büllöz pemfigoid daha çok yaşlı kişilerde görülür $(1,6,14)$. Yaşlı hastalarda çok sayıda hastalığın varlığı ve çoklu ilaç kullanılması, ilaç reaksiyonlarının daha çok ortaya çıkmasına neden olur. Akut ürtiker, büllü hastalıklar ve ilaç reaksiyonları yaşamı tehdit edebilecek, dermatolojik acil hastalıklardandır $(4,6)$. Ankara'da ve Elazığ'da yap1lan üç ayrı çalışmada ilaç reaksiyonlarının yaşlılarda \%1.4-4.8 sıklığında görüldüğü bildirilmiştir $(1,8,10)$. Çalışmamızda ilaç reaksiyonlarını \%0.7 sıklığında tespit ettik. Bu oranın diğer çalışmalardan daha düşük bulunmasinda hastaların daha sik acil servise başvurmaları rol oynamış olabilir.

Sonuç olarak, bölgemizde daha önce benzer bir çalışma yapılmamış olması nedeni ile çalışmamız Yozgat ilinde geriatrik yaş grubunda görülen deri hastalıkları hakkında bilgi vermektedir. Geriatrik hastalarda görülen dermatolojik problemler ve siklik oranlar1, Türkiye'nin çeşitli illerindeki merkezler arasında yapılan çalışmalarda değişkenlik göstermektedir. Ülkemizde geriatrik yaş grubunda görülen dermatolojik hastalıkları tam olarak tespit etmek ve gerekli önlemleri almak için aynı zaman diliminde yapılacak, prospektif, çok merkezli yeni çalişmalara ihtiyaç olduğunu düşünmekteyiz. 


\section{KAYNAKLAR}

1- Kokcam I, Dilek N. Yaşlı hastalarda görülen deri hastalıkları. Turkish Journal of Geriatrics 2007;10:113-116.

2- Demirseren DD, Emre S, Ateskan U, ve ark. Geriatri poliklinik hastalarında saptanan deri bulgularının prospektif analizi. Turkish Journal of Geriatrics 2010;13:87-91.

3- Bilgili SG, Karadag AS, Ozkol HU, et al. The Prevalence of Skin Diseases among the Geriatric Patients in Eastern Turkey. J Pak Med Assoc 2012;62:535-539.

4- Laube S. Skin infections and ageing. Ageing Res Rev 2004;3:69-89.

5- Norman RA. Geriatric dermatology. Dermatol Ther 2003;16:260-268.

6- Yaar M, Gilchrest BA. Aging of skin. In: Wolff K, Goldsmith LA, Katz SI, et al., editors. Fitzpatrick's Dermatology in General Medicine. $7^{\text {th }}$ ed. New York: Mc Graw Hill; 2008. p. 963973.
7- Bas Y, Kalkan G, Seçkin HY, ve ark. Geriatrik hastalarda dermatolojik sorunların analizi. Turk J Dermatol 2014;2:95-100.

8- Baykal Y, Karaduman A, Bükülmez G. Yașlı hastalarda deri sorunları. Turkish Journal of Geriatrics 1999;2:156-159.

9- Kılınç I, Ünal İ, Ceylan C, ve ark. Geriatrik hastalarda deri bulguları. Turkish Journal of Geriatrics 2002;5:103-106.

10- Yalcin B, Tamer E, Toy GG, et al. The prevalence of skin diseases in the elderly: analysis of 4099 geriatric patients. Int J Dermatol 2006;45:672676.

11- Şaşmaz S, Çelik M, Kerbiçer HÇ, ve ark. Yaşlılarda deri hastalıkları. Turkish Journal of Geriatrics 2003;6:5154.
12- Davis G, Luggen A. Geriatric nurse practitioner care guidelines: pruritus and xerosis in the elderly person. Geriatr Nurs 2003;24:247-248.

13- Kiliç A, Gül U, Aslan E, et al. Dermatological findings in the senior population of nursing homes in Turkey. Arch Gerontol Geriatr 2008;47:93-98.

14- Akyol A. Büllöz hastalıklar. Turkiye Klinikleri J Dermatol-Special Topics 2009;2:30-40. 
